\title{
PENGARUH MEDIA IKLAN TELEVISI SIRUP MARJAN TERHADAP KETERAMPILAN MENULIS CERPEN
}

\author{
Ratna Dewi Kartikasari, Anggia Pratiwi \\ Fakultas IImu Pendidikan, Universitas Muhammadiyah Jakarta \\ g4lih_58@yahoo.com
}

\begin{abstract}
Abstrak
Penelitian ini dilatarbelakangi oleh rendahnya keterampilan menulis cerpen siswa, sehingga peneliti tertarik untuk meneliti penyebab rendahnya keterampilan menulis cerpen siswa, serta memberikan solusi dengan menerapkan media iklan televisi dalam pembelajaran menulis cerpen. Adapun tujuan penelitian ini adalah untuk memudahkan, dan mendorong keterampilan menulis cerpen siswa menggunakan media iklan televisi. Penelitian ini merupakan penelitian kuantitatif. Metode yang digunakan dalam penelitian ini adalah eksperimen, dengan hipotesis adanya pengaruh media iklan televisi terhadap keterampilan menulis cerpen siswa. Populasi penelitian ini ialah siswa kelas XI SMAN 1 Parung, tahun 2017/2018 berjumlah 324 siswa terdiri atas 9 kelas. Sampel dalam penelitian ini diambil menggunakan teknik Probability Sampling, dengan dibagi menjadi dua kelompok. Kelas XI ipa 2 Berjumlah 30 siswa, sebagai kelas eksperimen, dan kelas XI ipa 3 berjumlah 30 siswa, sebagai kelas kontrol. Dari hasil penelitian yang telah dilakukan, bahwa media iklan televisi berpengaruh terhadap keterampilan menulis cerpen siswa. Hal ini dapat dilihat berdasarkan kriteria pengujian $t_{\text {hitung }}>t_{\text {tabel }}$ yaitu $(2,097>2,001)$. Terdapat perbedaan positif antara siswa yang menggunakan media iklan televisi dengan siswa yang tidak menggunakan media iklan televisi. Hasil penelitian ini diharapkan dapat bermanfaat bagi pihakpihak terkait memanfaatkan seperti, guru, siswa, serta peneliti selanjutnya.
\end{abstract}

Kata kunci: Media, iklan televisi, keterampilan menulis cerpen.

\section{PENDAHULUAN}

Bahasa Indonesia merupakan salah satu cabang ilmu dalam dunia pendidikan di Indonesia, baik dari tingkat SD, SMP, SMA bahkan perguruan tinggi sudah pasti tidak terlepas dari Bahasa Indonesia. Keterampilan berbahasa terdiri atas empat aspek, yaitu menyimak, berbicara, membaca, dan menulis. Menulis merupakan salah satu keterampilan berbahasa yang wajib diajarkan sejak anak mulai masuk sekolah dasar.

Di antara empat keterampilan tersebut, keterampilan menulis merupakan yang sangat penting dan sulit dikuasai terutama dalam pembelajaran Bahasa Indonesia. Menulis bukan suatu hal yang mudah, sebab dibutuhkan keterampilan yang mendalam tentang cara bagaimana mengembangkan gagasan yang ada di dalam pikiran menjadi sebuah tulisan. Menulis merupakan sebuah kegiatan belajar yang dilakukan oleh siswa untuk menuangkan gagasan atau ide yang ada dalam pikiran siswa. Selain untuk menuangkan gagasan atau ide, menulis juga bisa digunakan sebagai sarana berkomunikasi antar sesama. Agar komunikasi berjalan dengan baik, seseorang perlu berbahasa dengan baik dan benar. Maka, pembelajaran berbahasa disertakan dalam kurikulum di setiap jenjang pendidikan di sekolah. Keterampilan menulis tidak dapat dikuasai melalui teori saja, tetapi dilaksanakan melalui latihan dan praktik yang teratur sehingga mendapatkan hasil tulisan yang tersusun dengan baik.

Sejalan dengan pernyataan pada paragraf di atas (Tarigan, 2008: 3) menyatakan bahwa menulis merupakan suatu keterampilan berbahasa yang dipergunakan untuk berkomunikasi secara tidak langsung, tidak secara tatap muka dengan orang lain. Keterampilan menulis pada siswa dapat dikembangkan melalui berlatih menulis karangan, baik karangan fiksi maupun nonfiksi. Untuk menulis karangan fiksi, siswa dikhususkan untuk menulis cerpen atau puisi, karena dalam pembelajaran menulis di sekolah yang relatif pendek hanya memungkinkan untuk mempelajari menulis cerpen dan puisi. Dalam membuat cerpen, siswa harus mampu menggunakan imajinasinya masing-masing yang dapat diambil dari pengalaman pribadi atau kejadian-kejadian disekelilingnya yang menunjang penulisan sebuah cerpen. Maka kegiatan pembelajaran menulis cerpen dapat membuat siswa untuk lebih 
terbuka terhadap keadaan- keadaan disekitarnya. Sehingga melalui pembelajaran menulis cerpen ini siswa diharapkan dapat menumbuhkan jiwa sosialnya untuk peduli pada sesama.

Kegiatan pembelajaran menulis cerpen bukanlah hal yang mudah diajarkan kepada siswa, menulis cerpen bukan hanya keterampilan mengolah kata menjadi sebuah karangan, namun diperlukan imajinasi untuk dapat menghidupkan isi dari cerita tersebut. Banyak faktor yang menyebabkan siswa merasakan kesulitan dalam menulis cerpen. Salah satunya adalah metode dan media pembelajaran yang digunakan oleh guru, yang hanya menggunakan metode ceramah dan hanya buku sebagai medianya.

Menurut Asnawir dan Usman (2002: 11) media merupakan sesuatu yang bersifat menyalurkan pesan dan dapat merangsang pikiran, perasaan, dan kemauan siswa sehingga dapat mendorong terjadinya proses belajar pada dirinya. Penggunaan media secara kreatif akan memungkinkan siswa untuk belajar lebih baik dan dapat meningkatkan performa mereka sesuai dengan tujuan yang ingin dicapai. Untuk meningkatkan imajinasi dan kreativitas peserta didik, cara yang harus dilakukan oleh seorang guru adalah mempersiapkan metode dan media pembelajaran yang sesuai dengan materi ajar yang akan disampaikan, yaitu menulis cerpen. Sebuah media yang kreatif dan inovatif sangat dibutuhkan untuk memudahkan siswa belajar menulis. Salah satu media yang dapat meningkatkan imajinasi adalah media audiovisual yaitu iklan televisi. Baik secara langsung ataupun tidak langsung, tayangan televisi terutama iklan dapat memberikan dampak kepada penontonnya, yakni dampak positif ataupun dampak negatif.

Konsumen iklan bukan hanya di kalangan dewasa, para siswa terutama siswa SMA juga menjadi konsumen iklan saat melihat tayangan televisi. Ketika sebuah iklan televisi dapat menjadi sebuah hal yang dapat dijadikan media untuk pembelajaran, tentu dapat membantu siswa dalam belajar. Saat ini banyak sekali iklan yang tayang di televisi, salah satunya iklan sirup.

Dalam iklan sirup marjan banyak hal menarik seperti cerita bersambung yang membuat penontonnya menjadi penasaran akan kelanjutan cerita tersebut. Adanya alur dan amanat menunjukkan bahwa iklan tersebut dibuat dengan sangat baik dan bisa mempengaruhi penikmat televisi. Dengan adanya iklan yang memiliki alur, amanat, serta tokoh di dalamnya, iklan tersebut bisa dijadikan alat atau media untuk merangsang keinginan dalam menulis.

Berdasarkan hasil observasi yang penulis lakukan bahwa mata pembelajaran Bahasa Indonesia di kelas XI SMAN 1 Parung cenderung monoton dan membosankan. Hal tersebut dapat disimpulkan oleh peneliti berdasarkan wawancara yang telah dilakukan terhadapt guru mata pelajaran Bahasa Indonesia di sekolah tersebut. Salah satu penyebabnya adalah kurangnya inovasi serta keterlibatan siswa secara aktif pada setiap pembelajaran. Guru hanya menggunakan buku sebagai media dan metode ceramah dalam setiap pembelajarannya. Salah satunya dalam pembelajaran menulis cerpen di kelas XI SMAN 1 Parung. Pembelajaran menulis cerpen di kelas XI pada umumnya masih sangat rendah. Hal ini bisa disebabkan karena kurangnya ketertarikan siswa dalam pembelajaran Bahasa Indonesia terutama dalam pembelajaran menulis cerpen.

Inilah yang membuat penulis tertarik untuk melakukan penelitian disekolah tersebut. Media iklan televisi yang diberikan oleh guru diharapkan berpotensi menjadi media pembelajaran menulis cerita pendek yang efektif. Sebagaimana latar belakang yang sudah dijelaskan di atas maka dilakukan penelitian mengenai penggunaan media iklan televisi sebagai media pembelajaran menulis cerpen siswa. Penelitian ini berjudul "Pengaruh Media Iklan Televisi Terhadap Keterampilan Menulis Cerpen Siswa".

Media merupakan sesuatu yang bersifat menyalurkan pesan dan dapat merangsang pikiran, perasaan, dan kemauan siswa sehingga dapat mendorong terjadinya proses belajar pada dirinya. Penggunaan media secara kreatif akan memungkinkan siswa untuk belajar lebih baik dan dapat meningkatkan performa mereka sesuai dengan tujuan yang ingin dicapai (Asnawir dan Usman, 2002: 11).

Iklan merupakan bentuk kegiatan komunikasi non-personal yang disampaikan lewat media dengan membayar ruang yang dipakainya untuk menyampaikan pesan yang bersifat membujuk (persuasive) kepada konsumen oleh perusahaan, lembaga nonkomersial, maupun pribadi yang berkepentingan (Dunn dan Barban dalam Latief dan Utud, 2015: 216).

Televisi merupakan salah satu media massa yang memiliki audien paling besar dan 
sifat televisi yang disajikan dalam bentuk audio-visual membuatnya dapat dinikmati oleh berbagai kalangan, tak terkecuali anak-anak (Ardianto dan Erdinaya, 2005: 125).

Menulis merupakan suatu keterampilan berbahasa yang dipergunakan untuk berkomunikasi secara tidak langsung tidak secara tatap muka dengan orang lain. Menulis merupakan suatu kegiatan yang produktif dan ekspresif (Tarigan, 2008: 3).

Dikemukakan oleh Sumardjo dan Saini dalam Purba (2010: 50) bahwa cerita pendek (atau disingkat cerpen) adalah cerita yang pendek. Tetapi dengan hanya melihat fisik yang pendek orang belum dapat menetapkan sebuah cerita yang pendek adalah sebuah cerpen.

\section{METODE PENELITIAN}

Metode penelitian yang digunakan dalam penelitian ini adalah metode True experimental design dengan desain Posttest-Only Control Design. True experimental design melaksanakan kelompok kontrol maupun cara mengukur perubahan yang muncul dalam kedua kelompok. Menurut Sugiyono (2015: 76) dalam desain ini terdapat dua kelompok yang masing-masing dipilih secara random (R). Kelompok pertama diberi perlakuan $(\mathrm{X})$ dan kelompok yang lain tidak. Kelompok yang diberi perlakuan disebut kelompok eksperimen dan kelompok yang tidak diberi perlakuan adalah kelompok kontrol. Penelitian ini dilaksanakan di SMAN 1 Parung Bogor. Waktu Penelitian ini mulai Mei 2017 sampai Januari 2019.

Populasi adalah wilayah generalisasi yang terdiri atas objek atau subjek yang mempunyai kuantitas dan karakteristik tertentu yang ditetapkan oleh peneliti untuk dipelajari dan kemudian ditarik kesimpulannya. Misalnya akan melakukan penelitian di sekolah X, maka sekolah $\mathrm{X}$ ini mempunyai populasi yang bisa berupa jumlah subjek atau orang dan karakteristik subjek atau orang (Sugiyono, 2010: 61). Populasi dalam penelitian ini ialah siswa kelas XI SMAN 1 Parung tahun 2017/2018 yang berjumlah 324 siswa terdiri atas 9 kelas.

Sampel adalah bagian dari jumlah dan karakteristik yang dimiliki oleh populasi. Bila populasi besar, dan peneliti tidak mungkin mempelajari semua yang ada pada populasi, misalnya karena keterbatasan dana, tenaga, dan waktu, maka peneliti dapat menggunakan sampel yang diambil dari populasi itu. Apa yang diambil dari sampel, kesimpulannya akan dapat diberlakukan untuk populasi. Untuk itu sampel yang diambil dari populasi harus betul-betul representatif (mewakili). Sampel dalam penelitian ini dibagi menjadi dua kelompok, kelas XI IPA II yang berjumlah 30 orang siswa sebagai kelas eksperimen dan XI IPA III yang berjumlah 30 orang siswa sebagai kelas kontrol.

Teknik pengumpulan data dalam penelitian ini merupakan teknik tes. Gronlund dalam Nurgiyantoro (2014:7) berpendapat bahwa tes merupakan sebuah instrumen atau prosedur yang sistematis untuk mengukur suatu sampel tingkah laku, misalnya untuk menjawab pertanyaan "seberapa baik (tinggi) kinerja seseorang" yang jawabannya berupa angka. Instrumen yang digunakan dalam penelitian ini berupa tes. Instrumen tes yang digunakan berupa tes kemampuan menulis cerpen. Berikut ini merupakan kisi-kisi instrumen yang digunakan untuk mengumpulkan data.

\section{Tabel 1. Kisi-kisi Instrumen Penelitian}

\begin{tabular}{|l|l|l|l|l|}
\hline No. & Variabel & Materi & Indikator & \multicolumn{1}{|l|}{$\begin{array}{l}\text { Instrumen } \\
\text { Soal }\end{array}$} \\
\hline 1. & $\begin{array}{l}\text { Mem- } \\
\text { produksi } \\
\text { teks cerita } \\
\text { pendek } \\
\text { dengan } \\
\text { memerhatika } \\
\text { n unsur- } \\
\text { unsur } \\
\text { intrinsiknya }\end{array}$ & $\begin{array}{l}\text { Unsur } \\
\text { intrinsik } \\
\text { teks } \\
\text { cerita } \\
\text { pendek }\end{array}$ & $\begin{array}{l}\text { Siswa } \\
\text { dapat } \\
\text { menulis } \\
\text { teks cerita } \\
\text { pendek }\end{array}$ & $\begin{array}{l}\text { Dapat } \\
\text { menentukan } \\
\text { judul, dan } \\
\text { membuat teks } \\
\text { cerita pendek }\end{array}$ \\
\hline $\begin{array}{l}\text { Siswa } \\
\text { dapat } \\
\text { menulis } \\
\text { teks cerita } \\
\text { pendek } \\
\text { dengan } \\
\text { memerhatik } \\
\text { an tema, } \\
\text { Alur (Plot), }\end{array}$ & $\begin{array}{l}\text { Dapat } \\
\text { membuat teks } \\
\text { cerita pendek } \\
\text { dengan } \\
\text { mengunakan } \\
\text { unsur intrinsik } \\
\text { tens cerita } \\
\text { pendek }\end{array}$ \\
\hline $\begin{array}{l}\text { Latar, dan } \\
\text { Sudut } \\
\text { pandang }\end{array}$ & \\
\hline
\end{tabular}

Teknik analisis data yang digunakan dalam penelitian ini meliputi uji prasyarat analisis yaitu uji normalitas dan uji homogenitas. Uji normalitas digunakan untuk mengetahui data yang diperoleh dari kelas eksperimen dan kelas kontrol ini berdistribusi normal atau tidak. Dalam penelitian ini, uji normalitas populasi menggunakan uji Kolmogorov-Smirnov. Berikut langkah-langkah uji Kolmogorov-Smirnov.

1. Merumuskan hipotesis nol dan hipotesis alternatifnya

2. Menentukan FO (X)

3. Menentukan Sn (X) 
4. Menghitung besar simpangan terbesar dengan rumus: $\mathrm{D}=$ maksimum $|\mathrm{FO}(\mathrm{X})-\mathrm{Sn}(\mathrm{X})|$

5. Membuat kriteria pengeujian hipotesis dengan ketentuan terima Ho jika D < Dtabel

6. Dtabel = nilai kritis uji satu sampel Kolmogorov-Smirnov.

7. Membuat kesimpulan

Sedangkan uji homogenitas menggunakan uji Levene dengan bantuan Windows SPSS 20. Hal ini dilakukan untuk mengetahui apakah data tersebut berasal dari varians yang sama atau tidak. Hipotesis dalam uji homogenitas pada penelitian ini adalah sebagai berikut.

$\mathrm{H}_{0}=$ Kedua kelas mempunyai varians yang sama.

$\mathrm{H}_{1}=$ Kedua kelas mempunyai varians yang tidak sama.

Adapun kriteria pengambilan keputusannya adalah sebagai berikut.

1) Jika Sig $<\alpha$ maka $\mathrm{H}_{0}$ ditolak dan $\mathrm{H}_{1}$ diterima yang artinya data berasal dari populasi yang tidak homogen; $\alpha=0,05$

2) Jika Sig $\geq \alpha$ maka $\mathrm{H}_{0}$ diterima dan $\mathrm{H}_{1}$ ditolak yang artinya data berasal dari populasi yang homogen; $\alpha=0,05$

Hipotesis penelitian ini, peneliti menggunakan uji t independent (polled varian) dengan bantuan program Ms.Excel 2010 dengan taraf signifikansi 0,05 . Setelah pengolahan data maka diperoleh tampilan output sebagai berikut.

Uji t-independen ini digunakan untuk melihat apakah terdapat perbedaan keterampilan menulis cerpen siswa antara kelas eksperimen dengan kelas kontrol. Dalam perhitungannya, peneliti menggunakan bantuan software Ms.Excel 2010 sehingga diperoleh perhitungan seperti di bawah ini, dengan hipotesis pengujian sebagai berikut.

$H_{0}$ : Tidak terdapat perbedaan yang positif antara keterampilan menulis cerpen siswa yang diberikan media iklan televise (eskperimen) dengan siswa yang tidak diberikan media iklan televisi (kontrol).

$H_{1}$ : Terdapat perbedaan yang positif antara keterampilan menulis cerpen siswa yang diberikan media iklan televise (eskperimen) dengan siswa yang tidak diberikan media iklan televisi (kontrol).

Adapun kriteria pengujiannya adalah sebagai berikut.

1) Jika thitung > ttabel, maka H1 diterima dan H0 ditolak yang artinya terdapat perbedaan yang positif antara keterampilan menulis cerpen siswa yang diberikan media iklan televisi (eskperimen) dengan siswa yang tidak diberikan media iklan televisi (kontrol).

2) Jika thitung $\leq$ ttabel, maka $\mathrm{HO}$ diterima dan H1 ditolak yang artinya tidak terdapat perbedaan yang positif antara keterampilan menulis cerpen siswa yang diberikan media iklan televisi (eksperimen) dengan siswa yang tidak diberikan media iklan televisi (kontrol).

\section{HASIL DAN PEMBAHASAN}

Penelitian ini dilakukan di SMAN 1 Parung. Pembelajaran dilakukan sebanyak 4 pertemuan sekaligus posttest, masing-masing 2 pertemuan di kelas eksperimen dan 2 pertemuan di kelas kontrol. Sampel yang digunakan adalah 60 siswa kelas XI SMAN 1 Parung, 30 siswa pada kelas eksperimen dan 30 siswa pada kelas kontrol. Instrumen yang telah dianalisis diberikan kepada kelas eksperimen dan kontrol untuk mengetahui siswa mana yang memiliki kemampuan menulis cerpen lebih baik. Berikut data posttest dari masing-masing kelas.

Berdasarkan analisis data pada saat posttes, kelas eksperimen memperoleh nilai maksimum 98; nilai minimum 60 ; rentang 38 ; rata-rata 78,06; standar deviasi 9,67; varians 93,51; dan responden 30. Hasil perhitungan tersebut dapat dilihat pada tabel 4.1 berikut:

\section{Gambar 1. Distribusi Frekuensi Nilai Keterampilan Menulis Cerpen Siswa Kelas Eksperimen}

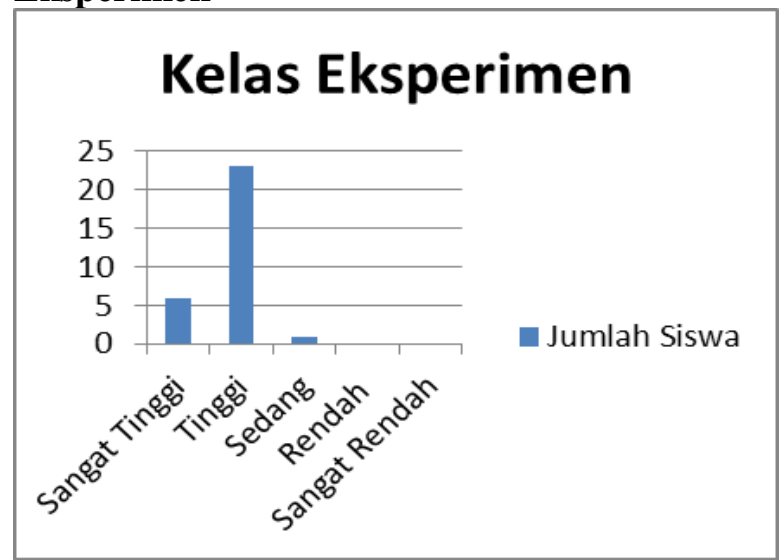

Berdasarkan gambar di atas kategori nilai siswa di kelas eksperimen yaitu 6 siswa memperoleh nilai sangat tinggi, 23 orang siswa memperoleh nilai tinggi, dan 1 orang siswa memperoleh nilai sedang. Sedangkan pada kelas kontrol diperoleh rata-rata skor 75,76, median 76 , 
modus 76,93, simpangan baku 4,090 Nilai terendah 64 dan nilai tertinggi 86.

Gambar 2. Distribusi Frekuensi Nilai Keterampilan Menulis Cerpen Siswa Kelas Kontrol

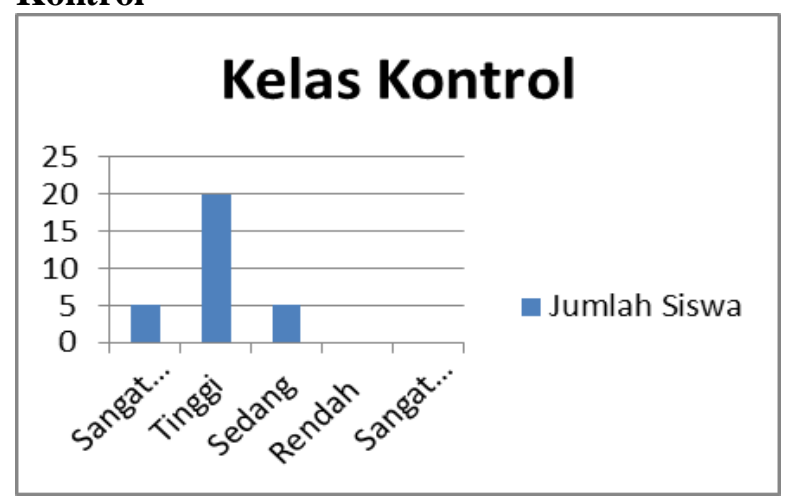

Berdasarkan gambar di atas kategori nilai keterampilan menulis cerpen siswa di kelas kontrol yaitu 5 siswa memperoleh nilai sangat tinggi, 20 orang siswa memperoleh nilai tinggi, dan 5 orang siswa memperoleh nilai sedang.

Uji normalitas ini menggunakan uji Kolmogrov-Smirnov dengan $\alpha=0,05$ baik untuk kelas eksperimen yang berjumlah 30 responden maupun untuk kelas kontrol yang berjumlah 30 responden.

Setelah dilakukan pengolahan data menggunakan bantuan Windows SPSS 20, tampilan output data dapat dilihat pada berikut.

Tabel 2. Uji Normalitas Data Kelas Eksperimen

\begin{tabular}{|l|l|l|l|l|l|l|}
\hline \multirow{2}{*}{ Kelas } & \multicolumn{3}{|c|}{$\begin{array}{c}\text { Kolmogrov- } \\
\text { Smirnov }\end{array}$} & A & Hipotesis & Keputusan \\
\cline { 2 - 7 } & Resp & K-S & Sig. & & & \\
\hline Eksperimen & 30 & 1,209 & 0,107 & & $\begin{array}{l}\mathrm{H}_{0} \\
\text { diterima }\end{array}$ & Normal \\
\hline Kontrol & 30 & 0,950 & 0,328 & 0,05 & $\begin{array}{l}\text { 刑 } \\
\text { diterima }\end{array}$ & Normal \\
\hline
\end{tabular}

Berdasarkan hasil output pada tabel 4.6, uji normalitas dengan menggunakan uji Kolmogrov-Smirnov, diperoleh nilai signifikansi keterampilan menulis cerpen siswa pada kelas eksperimen sebesar 0,107 dan kelas kontrol sebesar 0,328 dengan taraf signifikansi 0,05. Berdasarkan kriteria pengambilan keputusan, nilai signifikansi baik di kelas eksperimen maupun di kelas kontrol memperoleh nilai signifikansi lebih besar dari 0,05 , sehingga $\mathrm{H} 0$ diterima. Hal ini berarti bahwa sampel berasal dari populasi yang berdistribusi normal.

Uji homogenitas menggunakan uji Levene dengan bantuan Windows SPSS 20. Hal ini dilakukan untuk mengetahui apakah data tersebut berasal dari varians yang sama atau tidak. Hipotesis dalam uji homogenitas pada penelitian ini adalah sebagai berikut.

$\mathrm{H}_{\mathrm{o}}=$ Kedua kelas mempunyai varians yang sama. $\mathrm{H}_{1}=$ Kedua kelas mempunyai varians yang tidak sama.

Adapun kriteria pengambilan keputusannya adalah sebagai berikut.

1) Jika Sig $<\alpha$ maka H0 ditolak dan H1 diterima yang artinya data berasal dari populasi yang tidak homogen; $\alpha=0,05$

2) Jika Sig $\geq \alpha$ maka $\mathrm{H} 0$ diterima dan $\mathrm{H} 1$ ditolak yang artinya data berasal dari populasi yang homogen; $\alpha=0,05$

Setelah dilakukan pengolahan data menggunakan bantuan Windows SPSS 20, maka diperoleh tampilan output sebagai berikut.

\section{Tabel 3. Uji Homogenitas Menggunakan}

Levene-test

\begin{tabular}{|l|c|c|c|c|c|}
\hline $\begin{array}{c}\text { Levene } \\
\text { Statistic }\end{array}$ & df1 & df2 & Sig. & Hipotesis & Keputusan \\
\hline 0,025 & 1 & 59 & 0,875 & $\mathrm{H}_{0}$ diterima & Homogen \\
\hline
\end{tabular}

Berdasarkan hasil output pada tabel 4.7, uji homogenitas menggunakan Levene-test, diperoleh nilai signifikansi kemampuan penalaran matematika sebesar 0,875 dengan taraf signifikansi sebesar 0,05. Berdasarkan kriteria pengambilan keputusan, nilai signifikansi lebih besar dari $\alpha(0,05)$, sehingga $\mathrm{H}_{0}$ diterima. Hal ini berarti bahwa sampel berasal dari populasi yang homogen.

Pada analisis data peneliti menggunakan nilai keterampilan menulis siswa pada pelajaran Bahasa Indonesia materi cerita pendek. Peneliti manggunakan data untuk dianalisis dari nilai peserta didik kelas XI IPA II dan XI IPA III di SMA Negeri 1 Parung. Berdasarkan hasil analisis data pada saat posttes diperoleh hasil perhitungan pada kelas eksperimen memperoleh nilai maksimum 98 , nilai minimum 60 , rentan 38 , ratarata 78,06, standar deviasi 9,67, varians 93,51, dan responden 30. Sedangkan pada kelas kontrol memperoleh nilai maksimum 90 , nilai minimum 60 , rentan 30, rata-rata 73,1, standar deviasi 8,64, varians 74,71, dan responden 30 .

Berdasarkan analisis data dapat dilihat rata-rata skor untuk kelas eksperimen adalah 78,06 . Sedangkan rata-rata skor untuk kelas kontrol adalah 73,1. Dalam hal ini, kelas eksperimen mendapatkan perlakuan dengan menggunakan media iklan televisi dan kelas kontrol menggunakan pembelajaran biasa. Dalam 
perbandingan rata-rata skor dapat dilihat bahwa kelas eksperimen memiliki skor lebih tinggi dibandingkan dengan kelas kontrol.

Berdasarkan data yang telah diperoleh dan dideskripsikan sebelumnya, untuk menguji hipotesis penelitian, peneliti menggunakan uji $t$ independen (polled varian) dan uji $t$ paired (related sampel) dengan bantuan program Ms.Excel 2010 dan taraf signifikansi 0,05. Berdasarkan hasil uji $\mathrm{t}$ menggunakan uji $t$ independent (polled varian) diperoleh nilai $t_{\text {hitung }}$ sebesar 2,097 dan $t_{\text {tabel }}$ 2,001. Dengan demikian berdasarkan krieteria pengujian $t_{\text {hitung }}>t_{\text {tabel }}$ yaitu $(2,097>2,001)$, maka dapat disimpulkan bahwa $\mathrm{H}_{1}$ diterima yang artinya terdapat perbedaan positif antara siswa yang pembelajarannya menggunakan media iklan televisi dengan siswa yang tidak menggunakan media iklan televisi. Artinya media iklan televisi dalam pembelajaran ini berpengaruh terhadap keterampilan menulis cerpen pada siswa kelas XI di SMAN 1 Parung.

\section{KESIMPULAN}

Setelah dilakukan penelitian pada siswa kelas XI, maka dapat ditarik kesimpulan secara umum bahwa terdapat perbedaan keterampilan menulis cerpen pada siswa yang diberikan media iklan televisi (eksperimen) dengan siswa yang tidak diberikan media iklan televisi (kontrol). Kesimpulan tersebut diperoleh berdasarkan hasil perhitungan uji hipotesis menggunakan uji $t$ independen diperoleh $t_{\text {hitung }}$ sebesar 2,097 dan $t_{\text {tabel }}$ sebesar 2,001 sehingga $t_{\text {hitung }}>t_{\text {tabel }}(2,097>$ 2,001). Ini berarti bahwa media iklan televisi berpengaruh terhadap keterampilan menulis cerpen siswa kelas XI di SMAN 1 Parung.

Berdasarkan analisis pengolahan data dan pembahasan, diperoleh hasil penelitian. Pada kelas XI IPA II yang diberikan media iklan televisi (kelas eksperimen) diperoleh nilai ratarata posttest sebesar 78,06. Sedangkan untuk kelas XI IPA III yang tidak diberikan media iklan televisi (kelas kontrol) diperoleh nilai rata-rata posttest sebesar 73,1. Sehingga selisih dari kedua kelompok adalah sebesar 4,96. Dari data tersebut dapat disimpulkan bahwa perbedaan keterampilan menulis cerpen siswa di kelas eksperimen dengan keterampilan menulis cerpen siswa di kelas kontrol berdasarkan perolehan nilai rata-rata adalah sebesar 4,96.

\section{Referensi}

Ardianto, dan Erdiyana. 2005. Komunikasi Massa Suatu Pengantar. Bandung: Simbiosa Rekatama Media.

Asnawir dan Usman. 2002. Media Pembelajaran. Jakarta: Ciputat Pers.

Latief dan Utud. 2015. Siaran Televisi Keatif, Produktif, Public Relations, dan Iklan. Jakarta: Prenadamedia Group.

Nurgiyantoro, Burhan. 2012. Teori Pengkajian Fiksi. Yogyakarta: Gadjah Mada University Press.

Purba, Antilan. 2010. Sastra Indonesia Kontemporer. Yogyakarta: Graha Ilmu.

Sugiyono. 2010. Statistika untuk Penelitian. Bandung: Alfabeta

Tarigan, Henry Guntur. 2008. Menulis Sebagai Suatu Keterampilan Berbahasa. Bandung: Angkasa Bandung. 